\title{
THE ROLE OF QUALITY MANAGEMENT IN THE CONTEXT OF THE TRANSATLANTIC TRADE AND INVESTMENT PARTNERSHIP (TTIP): THE CASE OF THE POLISH AGRI-FOOD SECTOR
}

\author{
KATJA PIETRZYCK \\ BRIGITTE PETERSEN \\ SEBASTIAN JARZĘBOWSKI
}

\begin{abstract}
Since 2013, the European Union has been negotiating with the United States of America a Free Trade Agreement (FTA), the Transatlantic Trade and Investment Partnership (TTIP). A controversial topic in the negotiations are the different quality standards in the agri-food sectors of both negotiating partners. In order to put into force a FTA all the EU Member States have to agree to the implementation of the contract. Poland has been a full EU Member State since 1 May 2004 and gained a strong position within the EU. Thus, the importance of this EU Member State is of great relevance to the EU's trade policy. The main objective of this article is to analyse Poland's trading position and its domestic interests. The study primarily aimed at investigating the awareness of the TTIP in the agri-food sector with focus on the quality standards of this industry. There has been no in-depth discussion of this sensitive issue within Polish companies of the sector yet. In particular, the study identified an uncertainty regarding the application and interpretation of international standards in cross-border customersupplier relationships of food supply chains. For this reason, it is recommended to define these uncertainties and develop proposals for the harmonization and exploitation of synergies. In summary, the results have relevance for the sector.
\end{abstract}

Keywords: Transatlantic Trade and Investment Partnership (TTIP), Free Trade Agreement (FTA), agri-food sector, quality management, quality standards, food safety, Poland.

JEL codes: F14, F55, P45, Q17, Q18.

Dipl. Ing. Katja Pietrzyck, International FoodNetCenter, University of Bonn, Katzenburgweg 7-9,

53115 Bonn, Germany (katja.pietrzyck@uni-bonn.de);

Prof. Dr Brigitte Petersen, 1 International FoodNetCenter, University of Bonn, Katzenburgweg 7-9, 53115 Bonn, Germany (b-petersen@uni-bonn.de);

Dr hab. Sebastian Jarzębowski, Warsaw University of Life Sciences - SGGW; Faculty of Applied Informatics and Mathematics, ul. Nowoursynowska 166, 02-787 Warsaw, Poland (sebastian_jarzebowski@sggw.pl). 


\section{Introduction}

In June 2013, the European Union (EU) and the United States of America (US) turned towards intensive negotiations about a bilateral Transatlantic Trade and Investment Partnership (TTIP) (EC, 2013a). Since the beginning of 2017, negotiations with the US government have been paused (BMWi, 2018). In spring 2018, the US President - Donald Trump, threatened several countries to impose import tariffs on steel and aluminum (White House, 2018). Consequently, the EU is in close contact with the US and tries to turn the trade relations into positive ones and prevent punitive tariffs (EC, 2018a, 2018b, 2018c). As a result, business representatives, such as the Association of German Chambers of Commerce and Industry (DIHK) and the American Chamber of Commerce in Germany (AmCham), appealed for resumption of the TTIP negotiations on the grounds that such trade conflicts will not flare-up within an existing Free Trade Agreement (FTA) (DWN, 2018). After all, the TTIP has not yet been completely given up and there is a possibility that the talks will be resumed. The EU has underlined that this FTA will reduce regulatory barriers, thus having a positive impact on the EU foreign trade (EC, 2013b; BMWi, 2018).

The agreement covers a broad range of negotiating objectives; hence the focus of this paper is on the international quality standards of the agri-food industry, which are among the non-tariff trade barriers. The present paper is a sub-study of an on-going research project ( $\mathrm{PhD}$ studies) aiming to identify the role of quality standards under trade agreements. The focus of the present study is Poland.

This paper aims to verify the hypothesis that the knowledge about the TTIP is very low in the companies of the Polish agri-food industry, while confirming the importance of quality standards regarding foreign trade. As an empirical research method, a survey was conducted among experts in the sector.

\section{Poland's food industry at a glance in the context of the TTIP}

Poland has been a full EU Member State since 1 May 2004 and is on a good level as a global player with a strong position within the EU. The Ministry for Foreign Affairs developed the Polish Foreign Policy Strategy for 2017-2021, which considers the EU strategy. This contains a national liaison with the US (MFA, 2016, 2018). Poland mainly exports machinery, non-ferrous metals, transport equipment and services to the US (World Trade Institute, 2016).

Moreover, Poland is one of the most important food producers of the EU. The sector is dominated by small and medium-sized enterprises. First of all, it is the largest producer of apples, poultry meat and carrots. In addition, Poland has a significant share in production of white cabbage, rye, oat, triticale and dairy products (MARD, 2015). Polish food and beverages are popular abroad. Thus, an aim is to further boost exports. About one third of the Polish-made products are directly destined for export and with a ratio of $84 \%$, mostly exported to the EU Member States. The most important exporting countries (57\% share) are Germany, the United Kingdom, France, the Czech Republic, Italy and the Netherlands. The main 
EU importing countries are Germany, the Netherlands, Spain, Denmark and Italy, which accounts for 49\%. After the Russian embargo in August 2014, the exporters of agri-food products began efforts to enter alternative markets, for instance the US (GTAI, 2017a, 2017b, 2017c). According to the Ministry of Agriculture and Rural Development, Polish export "is a very important channel for utilizing surpluses and constitutes an import source of income for the domestic food industry" (MARD, 2015, p. 66). Due to Poland's distinctive position in terms of the value of food products, these commodities are competitive and recognized in many foreign markets (Wrzesińska-Kowal and Drabarczyk, 2014).

In the past, a number of studies were commissioned by the EU to assess the potential benefits and economic effects of the TTIP. These studies highlight the overall situation of all EU Member States (Ecorys, 2009; CEPR, 2013; Fontagné, Gourdon and Jaen, 2013; Felbermayr, Heid and Lehwald, 2013).

Regarding the TTIP effects on the Polish economy, the most important scientific study was published under the title The Impact of TTIP on Selected Sectors of the Polish Economy - an Analysis in 2016 (Dunin-Wąsowicz (eds.) et al., 2016). This study is based on qualitative and quantitative research and used the computable general equilibrium model the GTAP (Global Trade Analysis Project). Contrary to the aforementioned EU studies, this one figured out that the effects of the TTIP on the Polish market will be relatively moderate. With regard to the Polish agri-food sectors, it has been found that the share of total exports is generally rather marginal and, therefore, a significant increase in the foreign trade is not expected. Instantly, it is presumed that increased market access to the US could weaken Poland's strong position in the EU trade. In summary, it was noted that dynamic transatlantic trade is expected, with exports remaining marginal. Despite the TTIP, the existing barriers will be constraining foreign trade.

Another study outlined that a "too widely advanced liberalization of agricultural markets, especially for bovine, pork and poultry, may put the Polish farmers at a competitive disadvantage compared with farmers from third countries, who produce agricultural products cheaper, not only due to lower labor costs and/or optimal production structures, but also because they are not obliged to meet the tight EU standards for the environment or animal welfare, and who, in addition, are not obliged to exclude parts of the land from cultivation" (Kaliszuk, 2015, pp. 13-14). In addition, the study presents Poland's expectations and fears connected with the TTIP. The following negotiation points are considered as sensitive topics: issues of genetically modified organisms (GMO), food safety and sanitary and phytosanitary standards (SPS), protection of meat markets and a better access to the US markets (agricultural trade liberalization) (Kaliszuk, 2015). Similar results were also presented in a German study by Konrad-Adenauer-Stiftung (Maier, 2014).

Further significant studies which highlight the most important assumptions, objectives and scope of the TTIP regarding the Polish economies were conducted by Pawlak (2017), Hagemejer (2015), Grzelak and Roszko-Wójtowicz (2015), Pera (2015) and Hajdukiewicz (2014). 


\section{Poland's agricultural trade statistics}

Poland operates much of its trading business with the EU countries. Polish goods, destined for export, are in over 80\% distributed in the EU. Only 3\% are exported to Russia and $2 \%$ to the US. On the other hand, $72 \%$ of agricultural products are imported to Poland from other EU countries. In addition, 8\% come from China and $6 \%$ from Russia (CSO, 2017).

Table 1

Overview of import and export dates of selected product groups

\begin{tabular}{|c|c|c|c|c|c|}
\hline \multirow[t]{2}{*}{ Product group } & \multicolumn{2}{|c|}{ Import } & \multirow[t]{2}{*}{ Product group } & \multicolumn{2}{|c|}{ Export } \\
\hline & $\begin{array}{l}\text { Value } \\
\text { (USD } \\
\text { million) }\end{array}$ & $\%$ & & $\begin{array}{l}\text { Value } \\
\text { (USD } \\
\text { million) }\end{array}$ & $\%$ \\
\hline $\begin{array}{l}\text { Animal and vegetable } \\
\text { by products }\end{array}$ & 6.27 & 1.97 & $\begin{array}{l}\text { Animal and vegetable } \\
\text { by-products }\end{array}$ & 1.12 & 0.27 \\
\hline Margarine & 2.59 & 41.31 & Margarine & 0.691 & 61.7 \\
\hline Stearic acid & 2.22 & 35.41 & Rapeseed oil & 0.223 & 19.9 \\
\hline $\begin{array}{r}\text { Other pure } \\
\text { vegetable oils }\end{array}$ & 0.47 & 7.49 & $\begin{array}{r}\text { Other pure } \\
\text { vegetable oils }\end{array}$ & 0.146 & 13.1 \\
\hline Others & 0.99 & 15.79 & Others & 0.056 & 5.3 \\
\hline Animal products & 75.2 & 23.65 & Animal products & 123 & 29.57 \\
\hline Fish fillets & 49.9 & 66.36 & Pig meat & 91.3 & 74.23 \\
\hline $\begin{array}{l}\text { Non-fillet } \\
\text { Frozen fish }\end{array}$ & 21.9 & 29.12 & Cheese & 8.4 & 6.83 \\
\hline Others & 3.4 & 4.52 & Others & 23.3 & 18.94 \\
\hline Foodstuffs & 188 & 59.12 & Foodstuffs & 242 & 58.17 \\
\hline Wine & 40 & 21.28 & Chocolate & 46.4 & 19.17 \\
\hline $\begin{array}{l}\text { Other edible } \\
\text { preparations }\end{array}$ & 39.1 & 20.8 & Prepared meat & 44.4 & 18.35 \\
\hline Raw tobacco & 36 & 19.15 & Hard liquor & 27.6 & 11.4 \\
\hline Hard liquor & 27.8 & 14.79 & Processed fish & 22 & 9.1 \\
\hline $\begin{array}{r}\text { Processed } \\
\text { fruits and nuts }\end{array}$ & 14.2 & 7.55 & Baked goods & 15.2 & 6.3 \\
\hline Others & 30.9 & 16.43 & Others & 86.4 & 35.7 \\
\hline Vegetable products & 48.5 & 15.25 & Vegetable products & 49.6 & 11.92 \\
\hline Other nuts & 23.7 & 48.87 & Wheat & 13.5 & 27.2 \\
\hline Ground nuts & 4.27 & 8.8 & Frozen vegetables & 9.08 & 18.3 \\
\hline Vegetable juice & 3.93 & 8.1 & Dried vegetables & 7.05 & 14.2 \\
\hline Dried fruits & 3.47 & 7.15 & Starches & 6.04 & 12.2 \\
\hline Others & 13.13 & 27.08 & Others & 13.93 & 28.1 \\
\hline Total value & 318 & 100 & Total value & 416 & 100 \\
\hline
\end{tabular}

Source: own calculations upon OEC (2018). 
Poland's trade position with the US in all sectors can be illustrated by the following data. The current trade statistics show that in 2016, the total import value from the US to Poland amounted to USD 5.5 billion and the total value of exports was USD 4.81 billion. There is an evident export surplus. Regarding the agri-food sector, the total import value in 2016 was at about USD 318 million, share was at $5.8 \%$, and the total export value - USD 416 million, with a share of $8.6 \%$. It has been evaluated that the share of commodity flow in the agri-food sector is relatively low (OEC, 2018).

Table 1 reveals the import and export dates of selected product groups with the US (OEC, 2018). In the product group of animal and vegetable by-products, margarine accounts for the largest share of both imports (41.31\%) and exports (61.7\%). With regard to animal products, the most commonly imported products, the most commonly imported products are fish fillets $(66.36 \%)$ and the most commonly imported ones are pork meat $(74.23 \%)$. It should be noted that exports of butter accounted for only a small share of $0.71 \%$, with total amount of USD 878 thousand. Moreover, the share of milk exports was $0.19 \%$ and a total amount of USD 237 thousand. Therefore, both products have a very low share in trade. Poland is the EU's strongest producer of poultry meat. Although an increase in poultry meat production is taking place and export demand has increased, the US market plays only a very minor role. The main export markets continue to be the EU and Asia (USDA, 2016). With regard to hard liquor, more or less the same values were imported (USD 27.8 million) and also exported (USD 27.6 million). In addition, it can be stated that wheat exports have large share of $27.2 \%$ (OEC, 2018).

\section{Material and methods of the empirical analysis}

The research question requires to conduct an analysis. Data were collected with the use of empirical methods, i.e. a survey which was created and developed by own inquiries and was addressed to a very narrow specific target group. Only export-oriented companies from Poland were invited to participate in the survey. The interviews covered the most important experts from Poland's agri-food industry. The survey could be done online on an Internet platform as well as directly via paper questionnaire. The participants received a flyer, which pointed out detailed objectives of the research and defined the target group. A logo has been developed to clearly recognize this project. To access the survey, the web link and QR code were announced. The language of the survey has been adapted to the target group. Both the paper questionnaire and the online questionnaire were available in Polish, German and English.

The online survey was implemented with the use of the "EFS Survey" software of the Questback GmbH within the academic program "Unipark". The online survey was validated by consistency check and time exposure analysis. Voluntary and anonymous participation was ensured. In order to do a correct evaluation, the data from the paper questionnaires were transferred to the online tool by four eyes principle. The data export and the descriptive evaluation has been done with Microsoft Excel. The survey was divided into three technical parts and a statistical question part:

- Four questions about the TTIP,

- Four questions about the US trade, 
- Three questions about quality management,

- Four general questions.

Most questions were obligatory, and the answers were provided with the help of the Likert scale by ticking the selected box. Moreover, the respondent had the possibility to give optional comments and additional information (e.g. references to literature, sources, statistics, etc.) to the respective question in a free text field.

\section{Results and discussion}

Regarding the research question, the following results point out the most important empirical findings. Only the technical parts of the questionnaire were of relevance for the evaluation.

\section{Participants}

The target group of the survey included only experts in the export sector of the Polish agri-food industry; 150 participants were invited. The field report of the online survey indicates that 86 interested participants (gross participation) have accessed the survey. The participation rate is $57.3 \%$. Net participation, at 70 records, is $81.4 \%$. In total, 24 participants completed the full survey. The response rate is $27.9 \%$. These datasets were analysed.

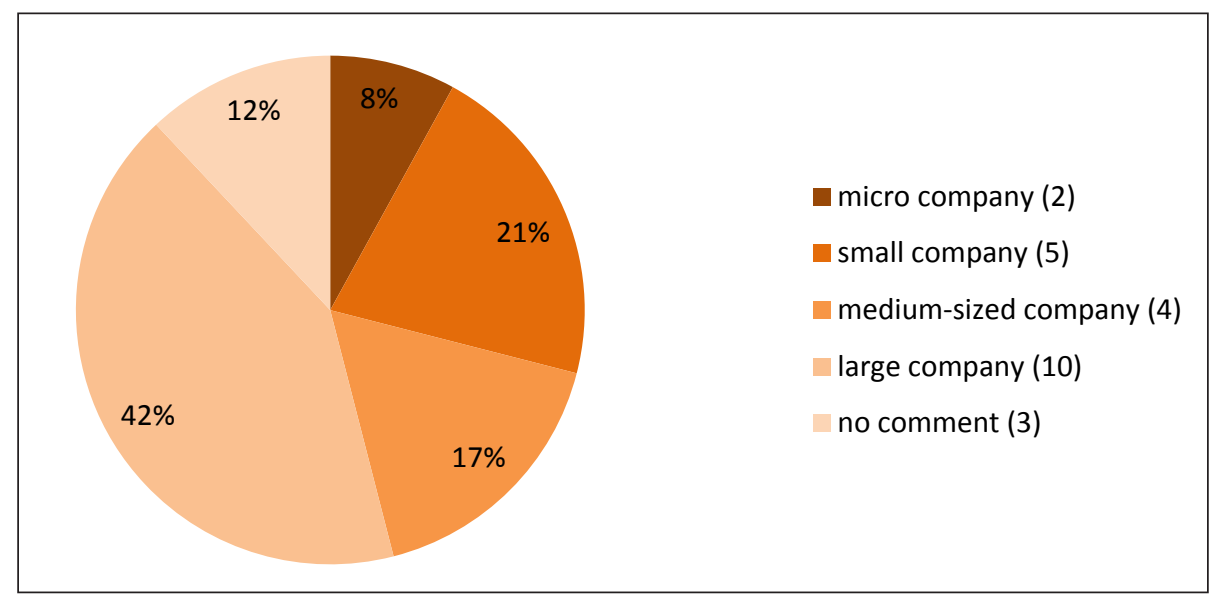

Fig. 1. Overview of allocation of different participating company categories $(n=24)$.

Source: own calculations.

The allocation of enterprises by specific branches is summarized as follows. In total, 24 agri-food companies took part in the survey. Eight companies (33.3\%) said they belonged to other branches of the industry for instance IT, consulting and analysis, logistic and transport and machinery production; $25.0 \%$ (six enterprises) were from fruit and vegetables, and potato industry. Three participants $(12.5 \%)$ were producers of dairy products (cheese, butter, milk, etc.). One respondent $(4.2 \%)$ was 
a producer of alcoholic beverages, meat and sausage products, fish products and plant production and one conducted animal breeding. Three participants $(12.5 \%)$ have not made a statement.

According to the EU definition for small and medium-sized enterprises (SMEs), agri-food companies can be broken down into four different entrepreneurial classes either according to their staff headcount or according to their turnover (EC, 2003).

- micro company (<10 employees, $\leq$ EUR 2 million turnover/year);

- small company $(<50$ employees, $\leq$ EUR 10 million turnover/year);

- medium-sized company (<250 employees, $\leq$ EUR 50 million turnover/year);

- large company (>250 employees, > EUR 50 million turnover/year).

Representatives of all business classes attended the survey. The large companies had the highest share in the survey $(41.7 \%)$. Three participants $(12.4 \%)$ provided no information on their company size. Figure 1 shows the allocation.

\section{The first section: knowledge regarding the TTIP}

At the beginning of the survey, panel participants should specify their sources of information about the TTIP. The respondents could mention their first to third choice in an open question. Multiple responses were possible. The answers indicate that there are no exact sources, only global generic terms. Resulting from that, the entrepreneurs obtain necessary information by means of secondary sources, as Figure 2 shows. The main source of information is generally the media (74\%), whereas the Internet plays a major role (49\%). However, it cannot be deduced which sources are used exactly, so that the quality of the information content cannot be estimated. It is notable, that no respondent has stated to obtain information from the institutions of the EU and the Polish government. Obviously, the associations of the agri-food industry play a minor role in gathering information about this topic.

In order to make a qualitative statement, the participants assessed the awareness of the TTIP in their company. As can be seen from Figure 3, it is estimated that the awareness of the FTA is low to very low; $33.3 \%$ are neutral on the topic. Only five respondents say that there is a high awareness of the TTIP in their enterprise.

Some participants have noted that they have no opinion or knowledge about the TTIP and its specificities. This shows clearly a gap in knowledge, and thus a disadvantage in foreign trade.

During the TTIP negotiations, some contentious issues were revealed, which are listed below:

- tariffs, import taxes, quotas (T, IT, Q);

- EU geographical indication (PDOs, PGIs, TSG) (EU-GI);

- procedures for rules of origin / evidence (RoO);

- local certifications, standards, security requirements (Cert/Stards);

- authorization procedures in the veterinary or phytosanitary sectors (vet/phyt);

- regulations on the use of pesticides (pesticides);

- processing times and administration costs for freight, registration, approvals, etc. (admin). 


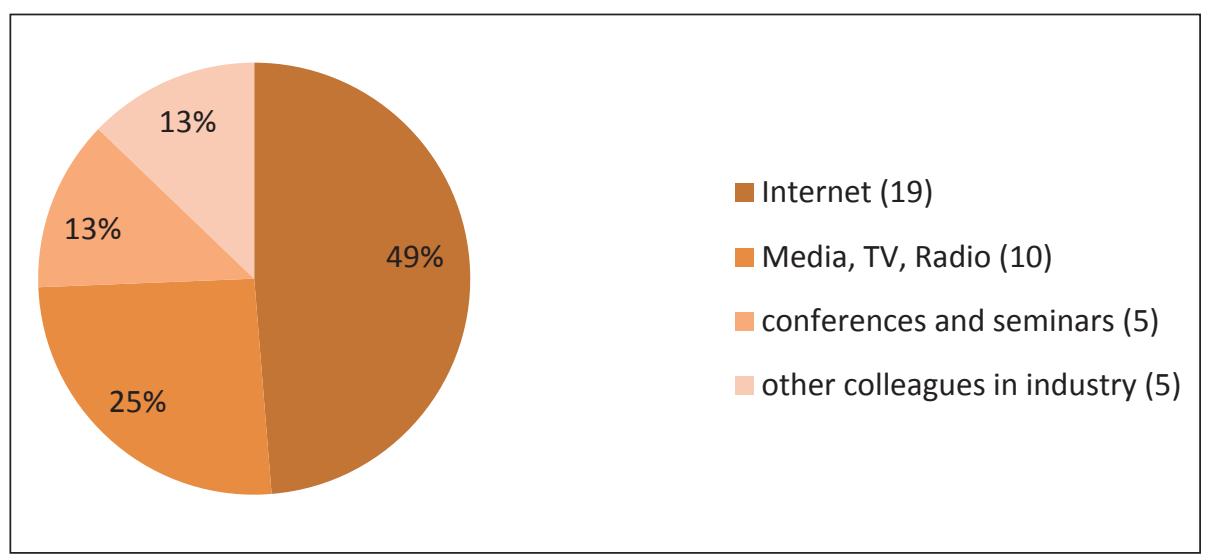

Fig. 2. Sources of information about the TTIP $(\mathrm{n}=39)$.

Source: own calculations.

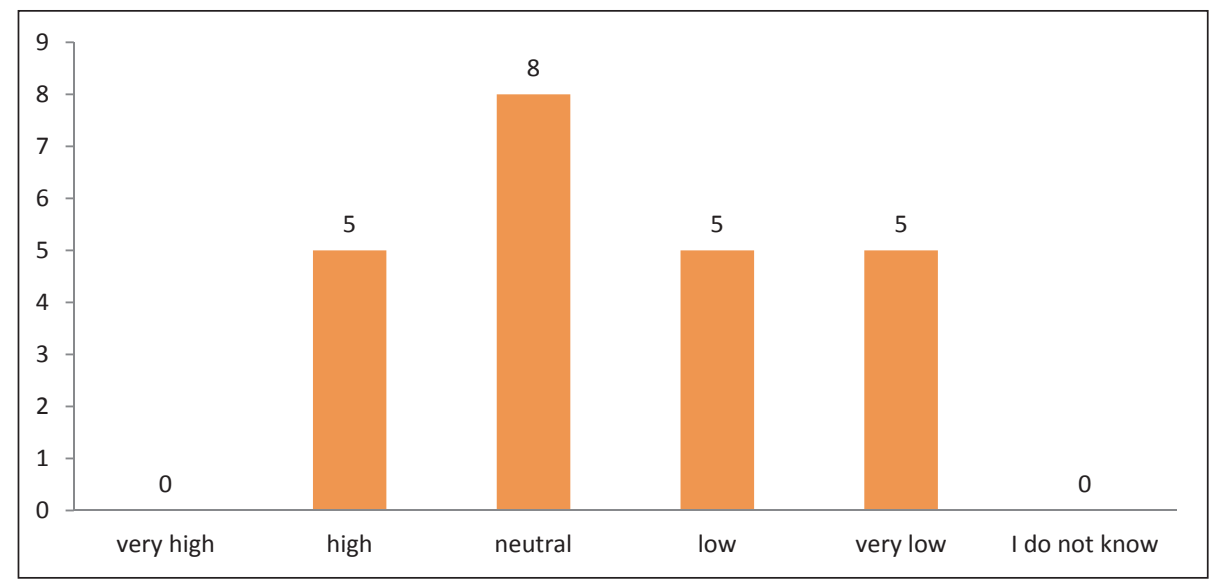

Fig. 3. Rating of awareness to the TTIP in the company $(\mathrm{n}=24)$.

Source: own calculations.

All the above topics are non-tariff trade barriers. To highlight these controversial negotiation topics, participants were asked to rate their significance for their own business. Table 2 shows the results. The respondents stress that the importance of all topics is generally high. Concerning the topic of standards and certification, nearly $80 \%$ of the participants assess this topic as of a high to very high importance. The issues, which are linked with the quality management such as the EU-GI labels $(43.5 \%)$ as well as the procedures for rules of origin $(75 \%)$, are also ranked from high to very high significance.

Overall, it should be noted that all non-tariff barriers to trade are of high importance within the TTIP negotiations for the agri-food sector. 
Table 2

Importance of established negotiating themes of non-tariff trade barriers in companies

\begin{tabular}{|c|c|c|c|c|c|c|c|c|c|c|c|c|c|c|}
\hline \multirow{2}{*}{$\begin{array}{c}\text { Level } \\
\text { of significance }\end{array}$} & \multicolumn{2}{|c|}{ T, IT, Q } & \multicolumn{2}{|c|}{ EU-GI } & \multicolumn{2}{|c|}{$\mathrm{RoO}$} & \multicolumn{2}{|c|}{ Cert/Stards } & \multicolumn{2}{|c|}{ vet/phyt } & \multicolumn{2}{|c|}{ pesticides } & \multicolumn{2}{|c|}{ admin } \\
\hline & $\Sigma$ & $\%$ & $\Sigma$ & $\%$ & $\Sigma$ & $\%$ & $\Sigma$ & $\%$ & $\Sigma$ & $\%$ & $\Sigma$ & $\%$ & $\Sigma$ & $\%$ \\
\hline $\begin{array}{l}\text { very high } \\
\text { importance }\end{array}$ & 5 & 21.7 & 2 & 8.7 & 5 & 20.8 & 8 & 33.3 & 7 & 29.2 & 4 & 16.7 & 8 & 34.8 \\
\hline $\begin{array}{l}\text { high } \\
\text { importance }\end{array}$ & 9 & 39.1 & 8 & 34.8 & 13 & 54.2 & 13 & 54.2 & 12 & 50 & 12 & 50 & 9 & 39.1 \\
\hline $\begin{array}{l}\text { medium } \\
\text { importance }\end{array}$ & 3 & 13.0 & 6 & 26.1 & 2 & 8.3 & 1 & 4.2 & 3 & 12.5 & 2 & 8.3 & 4 & 17.4 \\
\hline $\begin{array}{l}\text { minor } \\
\text { importance }\end{array}$ & 4 & 17.4 & 4 & 17.4 & 2 & 8.3 & 1 & 4.2 & 0 & 0 & 1 & 4.2 & 1 & 4.3 \\
\hline not significant & 1 & 4.3 & 1 & 4.3 & 1 & 4.2 & 0 & 0 & 1 & 4.2 & 4 & 16.7 & 0 & 0 \\
\hline I do not know & 1 & 4.3 & 2 & 8.7 & 1 & 4.2 & 1 & 4.2 & 1 & 4.2 & 1 & 4.2 & 1 & 4.3 \\
\hline $\mathrm{n}=$ & & 3 & & 3 & & 4 & & 4 & & 24 & & 4 & & 3 \\
\hline
\end{tabular}

Source: own calculations.

\section{The second section: knowledge regarding trade with the US}

The US is a key trading partner for all the EU Member States. For this reason, it is important to have relevant market knowledge about and an overview of the legal regulations in trade. Hence, it was necessary to ask to what extent the companies are familiar with this market. Moreover, it was important to know about their expectations and plans for the next twelve months. Nearly $74 \%$ of the respondents estimate their knowledge about the US market as minimal (Fig. 4). Only three participants believe that they have good skills. Nobody has developed very good knowledge about the US market. Only three participants estimate that they have good skills. For the second time, it has exposed a gap in knowledge.

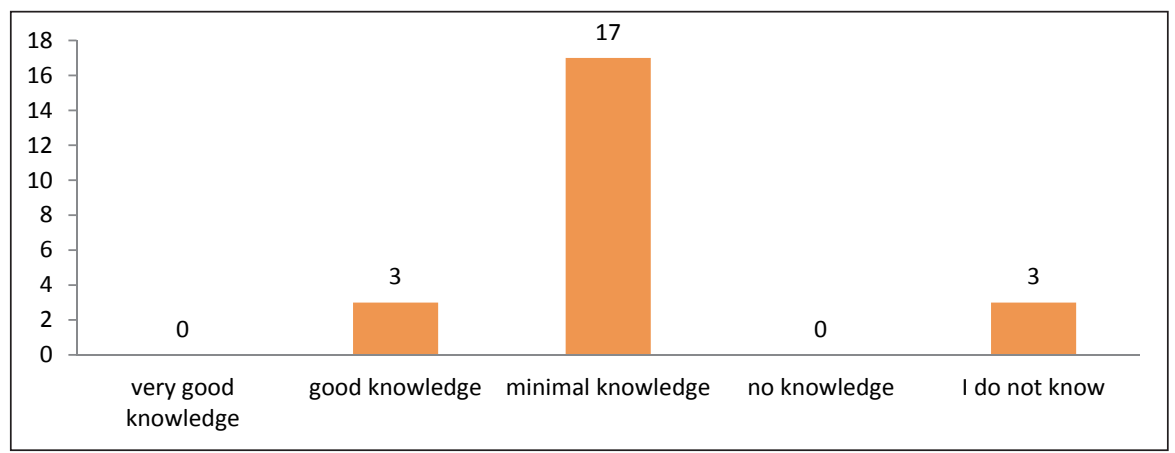

Fig. 4. Export competence (level of expertise) regarding the US market ( $\mathrm{n}=23)$.

Source: own calculations. 
The survey showed that the enterprises of the agri-food sector have a need for more support in the areas of legal security, information about new and modified regulations and consistent requirements. In addition, governmental export support programs are requested. These requirements could also be practiced in the area of quality management.

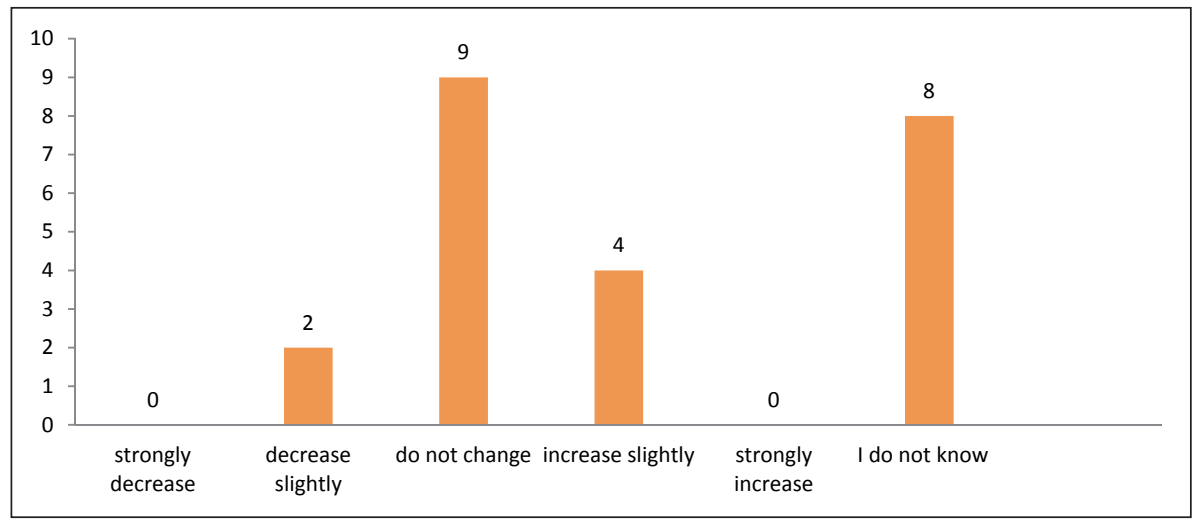

Fig. 5. Developments in the customer-supplier relationship in the agreement process over the next twelve months $(\mathrm{n}=23)$.

Source: own calculations.

In terms of the customer-supplier relationship, nine respondents $(39.1 \%)$ consider that the approval process between their US business partners along the value chain will not change over the next twelve months (Fig. 5). A strong increase or strong decrease in the length of the process is hardly to be expected. Ultimately, due to lack of experience, there are some uncertainties that are unpredictable, expressed by eight respondents $(34.8 \%)$, who do not imagine how their relationships between their US partners will change due to the TTIP. This precariousness should be eliminated through increased communication and capacity building.

As Figure 6 shows, the uncertainty is also reflected in the investment strategy of the companies. In the annual planning of the US trade activity, nine export-oriented enterprises $(39 \%)$ do not want to change their current investments in the US market. The majority (44\%) is noncommittal. Only $17 \%$ (four participants) want to increase their investments. It can be concluded that the TTIP negotiations incline to adopt a "wait-and-see" position in the transatlantic trade activities of the Polish companies, and that the propensity to invest initially stagnates until clear agreements are achieved. 


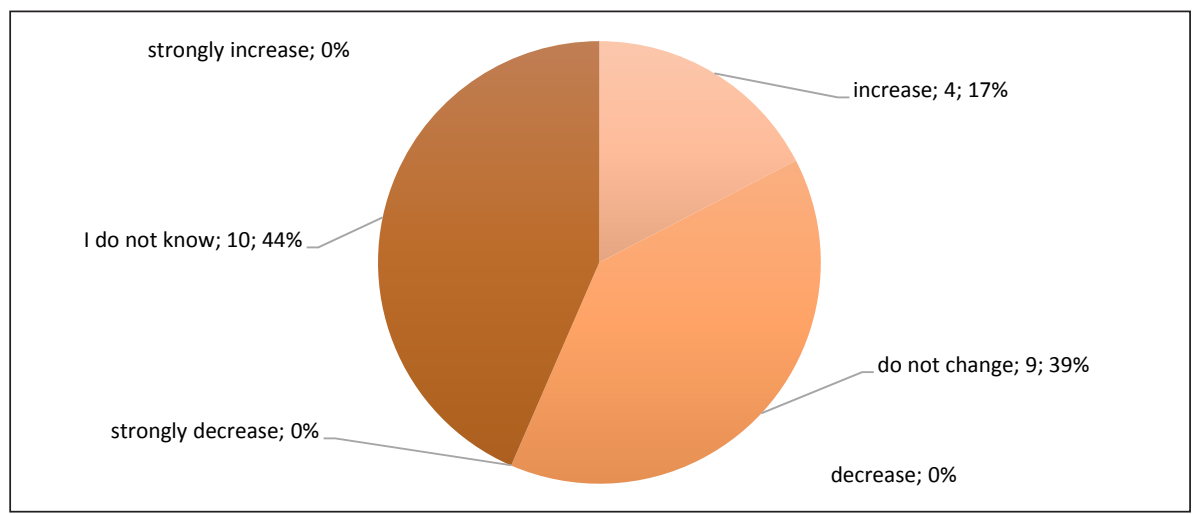

Fig. 6. The tendency of companies to invest in US exports in the next 12 months $(n=23)$. Source: own calculations.

\section{The third section: knowledge regarding quality management in agri-food sector}

Regarding quality management, respondents should assess the role of international quality standards in terms of the US trade. Furthermore, they should prognosticate the change through the TTIP agreement in terms of business with their US partners. The following phases should be considered:

- the role at the moment ( $1^{\text {st }}$ phase),

- the role during a transition period after the TTIP agreement entered into force ( $2^{\text {nd }}$ phase $)$,

- the role after consolidation of the TTIP agreement ( $3^{\text {rd }}$ phase).

According to nine respondents $(37.5 \%)$, the international quality standards play a large to very large role in all phases, whereby they will decrease a bit in the third phase (see Fig. 7). At least a quarter of the interviewees rate the importance as medium to low in all three phases. In the current first phase, four respondents (16.7\%) rate the standards as irrelevant. However, this will change over time, leading to their increased relevance.

In order to gain deeper insights into the utilization of the quality standards, a survey followed on the most popular standards (these were given) and their application spectrum in the company. The survey asked about four possible application scenarios for the specific standards:

- application for export to the US,

- application for export to other third countries,

- application for distribution in Poland,

- application for distribution to the EU Member States. 


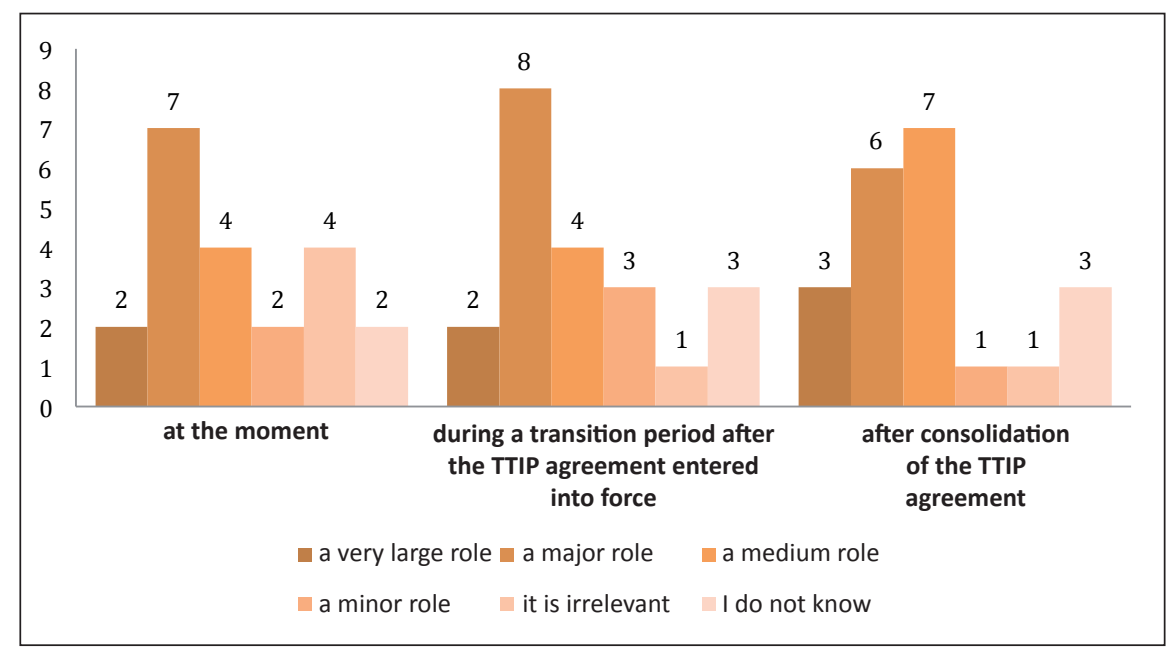

Fig. 7. The role and importance of quality standards in transatlantic trade plotted over time $(\mathrm{n}=24)$. Source: own calculations.

It yielded a surprising result, which is demonstrated in Table 3. It was found that the DIN EN ISO standards are hardly ever applied in all four scenarios. All in all, 66.7-85.7\% (14-18 replies) of respondents stated that the DIN EN ISO standards were not implemented. This was not expected because the assumption was that the DIN EN ISO standards were used in all export markets. In comparison, the private standards were given a higher relevance in the companies. The two main private standards are the IFS Food and BRC. Both are equally important in all four scenarios. Nonetheless, nine participants $(42.9 \%)$ said they had not implemented these standards. Furthermore, the two standards GlobalGAP and GMP+ are used, but not for export activities to the US and other third countries. These are only used for distribution in Poland and the other EU Member States. The QS standard was not implemented by $85.7 \%$ of respondents. In addition, it was stated that the standards of FSSC 22000, MSC and ASC and some Polish standards, for example PN-N-18001, are generally important.

Finally, the entrepreneurs were asked if there had been a disturbance in the US supply chain due to different standards in the past. Six respondents $(28 \%)$ indicated that they had already an interruption. The exact causes were not named. Other six participants did not know if there were such incidents. Nine companies (43\%) have not been affected by any supply chain disruptions due to different quality standards.

Although the survey has been conducted among export experts, there are gaps in knowledge about the TTIP. A study, carried out in 2014, showed that the Polish media hardly reported on the TTIP and there had been no public discussion so far. The topic was only superficially presented by the media. In addition, no counter movements have been established (Maier, 2014). The Polish media analysis concerning FTAs, created in 2017, showed a discrepancy between social perception and "expert knowledge". This finding is supported by the fact that more than a half of the examined media 
reports contained only very few scientific components $(\approx 8 \%)$. However, it was also noted that agri-food issues (e.g. GMO and food safety) had relatively high position in the media and played a significant role in reporting (Działo, Gawrońska-Nowak and Jura, 2017).

Table 3

Overview of international quality standards, which are implemented in Polish agri-food companies

\begin{tabular}{|c|c|c|c|c|c|c|c|c|c|c|}
\hline \multirow{2}{*}{$\begin{array}{c}\mathrm{n}=21 \\
\text { International standards }\end{array}$} & \multicolumn{2}{|c|}{$\begin{array}{l}\text { Implemented } \\
\text { for export } \\
\text { to the US }\end{array}$} & \multicolumn{2}{|c|}{$\begin{array}{l}\text { Implemented } \\
\text { for export } \\
\text { to other third } \\
\text { countries }\end{array}$} & \multicolumn{2}{|c|}{$\begin{array}{l}\text { Implemented } \\
\text { for } \\
\text { distribution } \\
\text { in Poland }\end{array}$} & \multicolumn{2}{|c|}{$\begin{array}{l}\text { Implemented for } \\
\text { distribution } \\
\text { to the EU } \\
\text { Member States }\end{array}$} & \multicolumn{2}{|c|}{$\begin{array}{c}\text { None } \\
\text { standards } \\
\text { implemented }\end{array}$} \\
\hline & Yes & No & Yes & No & Yes & No & Yes & No & Yes & No \\
\hline $\begin{array}{l}\text { DIN EN ISO } \\
9000 \mathrm{ff} \text { (quality } \\
\text { management system } \\
\text { standards) }\end{array}$ & 1 & 20 & 1 & 20 & 3 & 18 & 4 & 17 & 15 & 6 \\
\hline $\begin{array}{l}\text { DIN EN ISO } 19011 \\
\text { (guidelines for auditing } \\
\text { management systems) }\end{array}$ & 0 & 21 & 0 & 21 & 1 & 20 & 1 & 20 & 18 & 3 \\
\hline $\begin{array}{l}\text { DIN EN ISO } 22000 \\
\text { (Food safety } \\
\text { management } \\
\text { system standard) }\end{array}$ & 1 & 20 & 1 & 20 & 5 & 16 & 5 & 16 & 14 & 7 \\
\hline $\begin{array}{l}\text { other international } \\
\text { standards }\end{array}$ & 2 & 19 & 1 & 20 & 2 & 19 & 3 & 18 & 17 & 4 \\
\hline $\begin{array}{l}\text { International private } \\
\text { standards }\end{array}$ & Yes & No & Yes & No & Yes & No & Yes & No & Yes & No \\
\hline $\begin{array}{l}\text { IFS Food (International } \\
\text { Featured Standard) }\end{array}$ & 6 & 15 & 7 & 14 & 9 & 12 & 10 & 11 & 9 & 12 \\
\hline $\begin{array}{l}\text { BRC (British Retail } \\
\text { Consortium) }\end{array}$ & 7 & 14 & 7 & 14 & 9 & 12 & 10 & 11 & 9 & 12 \\
\hline $\begin{array}{l}\text { QS Standard (Qualität } \\
\text { und Sicherheit GmbH) }\end{array}$ & 0 & 21 & 0 & 21 & 0 & 21 & 1 & 20 & 18 & 3 \\
\hline GlobalGAP & 3 & 18 & 3 & 18 & 7 & 14 & 6 & 15 & 13 & 8 \\
\hline GMP+ & 0 & 21 & 2 & 19 & 4 & 17 & 4 & 17 & 14 & 7 \\
\hline other private standards & 2 & 19 & 2 & 19 & 2 & 19 & 2 & 19 & 18 & 3 \\
\hline
\end{tabular}

Source: own calculations.

\section{Conclusions}

The rapid transformation of foreign trade, intensified by the EU's trade policy and novel Free Trade Agreements (FTAs), is a challenge for all stakeholders in the food supply chain. This leads to the need to constantly improve knowledge and skills, in particular in quality management. To better understand the attitude to the FTAs, in 
this case specifically the TTIP, this study analysed the trade position and domestic interests of Poland by reviewing the relevant literature and trade figures. Moreover, a survey among experts of the agri-food sector was conducted aimed to examine the awareness of the TTIP and the status of knowledge about the US trade in the context of quality management. The choice of Poland was motivated by its strong position in the EU. The agricultural trade statistics confirm that Poland is one of the leading exporters of foodstuff and a robust global actor as an EU Member State. Consequently, Polish trade activities are taking place predominantly within the European countries. Hence, the US is of minor importance to Poland. In particular, the expert survey focused deeply on the industry. In this respect, the investigated sample of 24 export experts revealed unique results around these challenges. Although the findings cannot be generalized, because the study was conducted on Polish enterprises with a sample that was not representative of the entire Polish agri-food industry, they provide some novel contributions to the current debate on the role of quality standards in the context of the FTAs. The hypothesis was verified. As a result, it has been confirmed that the knowledge about the TTIP and the US-trade is very restricted. Gaps in knowledge and lacks of experience were identified in each specific part. The survey also validated the importance of international quality standards, revealing that private standards play a greater role than the DIN ISO standards.

The key message from this paper is that some necessary improvements should should be made. Firstly, it is essential for export-oriented companies to strengthen their competitiveness in sharing and improving knowledge and skills on foreign trade, in particular the US. Secondly, it is worth encouraging economic development by means of innovative quality management and ongoing elaboration, harmonization of international quality standards. And finally, helping companies acquire the skills needed to realize a high quality management will be equally crucial. Capacity building should be a major goal. These aspects provide some important indications for further research, not only in Poland, but also throughout the EU. 


\section{References}

BMWi (2018). Transatlantische Handels- und Investitionspartnerschaft (TTIP). Retrieved from: www.bmwi.de/Redaktion/DE/Dossier/ttip.html.

CEPR (2013). J. Francois, M. Manchin, H. Norberg, O. Pindyuk, P. Tomberger (ed.). Reducing Transatlantic Barriers to Trade: An Economic Assessment Prepared for the European Commission. Final Project Report. London: Centre for Economic Policy Research (CEPR).

CSO - Central Statistical Office (2017). Production and foreign trade of agricultural products in 2016. Statistical Information and Elaborations. GUS. Departament Rolnictwa. Warszawa 2017. ISSN 1507-9449. Retrieved from: www.stat.gov.p1/.

Dunin-Wąsowicz, M. (eds.), Czarny, E., Hagemejer, J., Michałek, J.J., Paliński, M., Pawlak, K., Syliwoniuk, M., Śledziewska, K. (2016). The Impact of TTIP on Selected Sectors of the Polish Economy - an Analysis. Wydawnictwo Naukowe Scholar.

DWN - Deutsche WirtschaftsNachrichten (2018). EU will TTIP-Verhandlungen wieder aufnehmen. Issued on 15 March 2018. Retrieved from: www.deutsche-wirtschafts-nachrichten. de/2018/03/15/eu-will-ttip-verhandlungen-wieder-aufnehmen/.

Działo, J., Gawrońska-Nowak, B., Jura, J. (2017). Social Debate on Free Trade Agreements: Illusions Versus Reality. Economics and Sociology. 10(3), pp. 116-135. DOI:10.14254/2071$-789 X .2017 / 10-3 / 9$.

EC (2003). What is an SME? Small and medium-sized enterprises (SMEs) are defined in the EU recommendation 2003/361. Retrieved from: www.ec.europa.eu/growth/smes/business-friendly-environment/sme-definition/.

EC (2013a). Transatlantic Trade and Investment Partnership: Commissioner Karel De Gucht welcomes Member States' green light to start negotiations. Retrieved from: www.trade. ec.europa.eu/doclib/press/index.cfm?id=917.

EC (2013b). Member States endorse EU-US trade and investment negotiations. Retrieved from: www.europa.eu/rapid/press-release_MEMO-13-564_en.htm.

EC (2018a). European Commission responds to the US restrictions on steel and aluminium affecting the EU. Press release on 1 March 2018. Retrieved from: http://trade.ec.europa.eu/ doclib/press/index.cfm?id=1805

EC (2018b). Commission launches safeguard investigation into steel products to prevent trade diversion into the EU. News on 26 March 2018. Retrieved from: http://trade.ec.europa.eu/ doclib/press/index.cfm?id=1823

EC (2018c). Commission statement following US announcement of an extension until 1 June of the EU's exemption from US tariffs on steel and aluminium imports. News on 1 May 2018. Retrieved from: www.trade.ec.europa.eu/doclib/ press/index.cfm? id=1839.

Ecorys (2009). Non-tariff Measures in EU-US Trade and Investment-An Economic Analysis. Rotterdam: ECORYS Nederland BV (authors: Dr. K. G. Berden, Prof. Dr. J. Francois, Mr. M. Thelle, Mr. P. Wymenga, Ms. S. Tamminen). Final Report for the European Commission, Directorate-General for Trade Reference: OJ 2007/S 180-219493.

Felbermayr, G., Heid, B., Lehwald, S. (2013). Transatlantic Trade and Investment Partnership (TTIP). Who benefits from a free trade deal? Part 1: Macroeconomic effects. Gütersloh. Bertelsmann Stiftung.

Fontagné, L., Gourdon, J., Jaen, S. (2013). Transatlantic Trade: Whither Partnership, Which Economic Consequences? CEPII Policy Brief No. 1. Paris: CEPII. Retrieved from: www. cepii.fr/PDF_PUB/pb/2013/pb2013-01.pdf.

Germany Trade \& Invest - GTAI. (2017a). Retrieved from: www.gtai.de/ GTAI/Navigation/ DE/Trade/Maerkte/suche,t=polen-automatisiert-verpackungsprozesse, did=1789388.html. 
Germany Trade \& Invest - GTAI. (2017b). Retrieved from: www.gtai.de/GTAI/ Navigation/DE/ Trade/Maerkte/suche,t=nahrungsmittel-aus-polen-sind-weltweit-gefragt,did=1649720.html.

Germany Trade \& Invest - GTAI. (2017c). Pobrane z: https://www.gtai.de/ GTAI/Navigation/ DE/Trade/MaerkteBranchen/Branche-kompakt/branche-kompakt-ernaehrungswirtschaft ,t=branche-kompakt-ernaehrungswirtschaft-profitiert-von-wachsendem-wohlstand-inpolen, did=1672030.html\#Marktchancen.

Grzelak, M.M., Roszko-Wójtowicz, E. (2015). Development of Polish foreign trade in agri-food products after Poland's accession to the EU. Acta Scientiarum Polonorum, Oeconomia, no. 14(4), pp. 37-48. Retrieved from: www.yadda.icm.edu.pl/yadda/element/bwmeta1.element. agro-371b72a7-5fdf-4439-8143-177f983686c1.

Hagemejer, J. (2015). Liberalization of trade flows under TTIP from a small country perspective. The case of Poland. University of Warsaw. Faculty of Economic Science. Working Papers No. 17/2015 (165). Retrieved from: www.wne.uw.edu.pl/files/4514/3231/9323/WNE_WP165.pdf.

Hajdukiewicz, A. (2014). Agricultural issues in the negotiations of the Transatlantic Trade and Investment Partnership. International Business and Global Economy, No. 33. pp. 285-296. DOI: $10.4467 / 23539496$ IB.13.020.2405.

Kaliszuk, E. (2015). Transatlantic Trade and Investment Partnership: Polish perspective. The Journal of International Relations, National Chenchi University, Taipei, vol. 39, pp. 2-47.

Maier, W. (ed.). (2014). Konrad-Adenauer-Stiftung e. V. Die Wahrnehmung von TTIP im Ausland: Stimmungsbilder aus Europa und den USA.

Ministry of Agriculture and Rural Development - MARD (2015). Agriculture and Food economy in Poland. Collective work edited by the Institute of Agricultural and Food Economics. Retrieved from: www.ijhar-s.gov.pl/index.php /agricultural-and-food-economy-in-poland.html.

Ministry of Foreign Affairs of the Republic of Poland - MFA (2016). Polish Foreign Policy Strategy 2017-2021. Retrieved from: www.msz.gov.pl/resource/0c98c3b2-9c5d-4c42-8761-f7827134ee76:JCR.

Ministry of Foreign Affairs of the Republic of Poland - MFA (2018). Foreign policy. Goals of the foreign policy. Our priorities. Retrieved from: http://www.msz.gov.pl/en/foreign_policy/goals_of_foreign_policy/.

OEC - The Observatory of Economic Complexity (2018). Retrieved from: https://atlas.media. mit.edu/en/visualize/tree_map/hs92/import/pol/usa/show/2016/ (access date: 18.04.2018).

Pawlak, K. (2017). The Importance of the Bilateral Turnover to the EU and the US Foreign Trade in Agri-food Products. Zeszyty Naukowe SGGW, Problemy Rolnictwa Światowego, vol. 17(32), no. 2, pp. 199-210. DOI: 10.22630/PRS.2017.17.2.39.

Pera, B. (2015). Market access conditions for Polish products to the US market in the context of the Transatlantic Trade and Investment Partnership. Zeszyt naukowy the Scientific Journal no 38 of the School of Banking and Management in Krakow. Retrieved from: www.zeszytnaukowy.pl/ download.php?article=1132.

USDA - United States Department of Agriculture. Foreign Agricultural Service - FAS. (2016). Poland maintains its leading position in the EU. Retrieved from: www.fas.usda.gov/data/ poland-poland-maintains-its-leading-position-eu.

White House (2018). Presidential Proclamation on Adjusting Imports of Steel into the United States. Retrieved from: www.whitehouse.gov/presidential-actions/ presidential-proclamationadjusting-imports-steel-united-states/ (Issued on: March 8, 2018).

World Trade Institute (2016). TTIP and the EU Member States. World Trade Institute, University of Bern, Bern, January 2016.

Wrzesińska-Kowal, J., Drabarczyk, K. (2014). Food production in Poland, compared to selected European Union Member States. Scientific Journal Warsaw University of Life Science SGGW. Problems of World Agriculture, vol. 14(XXIX), no. 4, 2014, pp. 205-214. 


\title{
ROLA ZARZĄDZANIA JAKOŚCIĄ \\ W KONTEKŚCIE TRANSATLANTYCKIEGO PARTNERSTWA HANDLOWO-INWESTYCYJNEGO (TTIP): \\ NA PRZYKŁADZIE POLSKIEGO \\ SEKTORA ROLO-SPOŻYWCZEGO
}

\begin{abstract}
Abstrakt
Od 2013 roku Unia Europejska prowadzi negocjacje ze Stanami Zjednoczonymi Ameryki w sprawie umowy o wolnym handlu (FTA), transatlantyckie partnerstwo handlowo-inwestycyjne (TTIP). Kontrowersyjnym tematem w negocjacjach sa odmienne standardy jakości w sektorach rolno-spożywczych obu partnerów negocjacyjnych. W celu wprowadzenia w życie umowy o wolnym handlu wszystkie państwa członkowskie UE musza wyrazić zgodę na wdrożenie umowy. Polska jest petnym państwem członkowskim UE od 1 maja 2004 roku i zdobyła silna pozycję w UE. W związu z tym Polska jako członek unii ma ogromne znaczenie dla polityki handlowej UE. Głównym celem tego artykułu jest analiza polskiej pozycji handlowej i jej interesów krajowych. Badanie miało na celu przede wszystkim zbadanie świadomości na temat TTIP w sektorze rolno-spożywczym, ze szczególnym uwzględnieniem standardów jakości w tej branży. Nie przeprowadzono jeszcze dogłębnej dyskusji na temat tego delikatnego zagadnienia $w$ polskich przedsiębiorstwach tego sektora. W szczególności określono niepewność dotyczaca stosowania $i$ interpretacji międzynarodowych norm $w$ transgranicznych relacjach klient-dostawca łańcuchów dostaw żywności. Z tego powodu zaleca się zdefiniowanie tych niepewności i opracowanie wniosków dotyczacych harmonizacji i wykorzystania synergii. Podsumowując, wyniki sa istotne dla sektora.
\end{abstract}

Słowa kluczowe: transatlantyckie partnerstwo handlowo-inwestycyjne (TTIP), umowa o wolnym handlu (FTA), sektor rolno-spożywczy, zarządzanie jakością, normy jakościowe, bezpieczeństwo żywności, Polska.

Accepted for print: 5.09.2018.

Unless stated otherwise all the materials on the website are available under the Creative Commons Attribution 4.0 International license.

Some rights reserved to the Institute of Agricultural and Food Economics - National Research Institute.

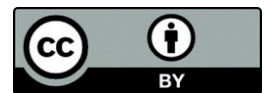

